\title{
Güvercinde (Columbidae columbiformes) Pekten Okulinin Histomorfolojik
}

\author{
Yapısı
}

\author{
Deniz KORKMAZ \\ Harran Üniversitesi, Veteriner Fakültesi, Histoloji Embriyoloji Anabilim Dalı, Şanlıurfa, Türkiye.
}

Geliș Tarihi: 10.04.2017

Kabul Tarihi: 09.05.2017

\begin{abstract}
Özet: Yapılan çalışmada güvercinde pekten okulinin histomorfolojik olarak araştırılması ve diğer kanatlı türleriyle farklılıklarının ortaya konulması amaçlandı. Çalışma materyalini Veteriner Fakültesi Hayvan Hastanesine getirilen ve kurtarılamayan iki adet güvercinlerden alınan sağlıklı göz dokusu örnekleri oluşturdu. Alınan doku örnekleri \%10'luk nötral tamponlu formalin solüsyonunda 24 saat tespit edildi. Rutin doku takip işlemlerinden sonra bloklanan örneklerden seri kesitler alındı. Alınan bu kesitler Crossman'ın üçlü boyama yöntemiyle boyanarak araştırma mikroskobunda incelendi. Diğer kanatlı türlerinde olduğu gibi güvercinde de pekten okulinin nervus optikusun retinaya giriş bölgesinden vitreusa doğru uzandığı tespit edildi. Diğer kanatıılardan farklı olarak güvercinde pekten okulinin oturduğu kalın bazal laminada retinanın tamamıyla kopuntuya uğramadığı, optik sinir telleri katının bir süre daha devam ettiği görüldü. Pektenin oturduğu bazal kısımda büyük çaplı damarlara rastlandı. Bu damarların koroidden gelen damardan köken aldığı belirlendi. Bazalden apikale doğru gidildikçe damar çaplarının küçüldüğü tespit edildi. Bu nedenle damarlar çaplarına göre primer, sekonder ve tersiyer damarlar olarak sınıflandırıldı. Sınıflandırılan her damar grubundan rastgele örnekleme yöntemiyle 20 tanesinin çapları ölçülerek, ortalama damar çapı değerleri elde edildi. Pektenin bazal kısmında ayrıca az miktarda melanositlere de rastlandı. Bu melanositlerin de koroidin lamina vaskulozasında bulunan melanositlerden köken almış olabileceği düşünüldü. Pektenin apikale doğru uzanan kıvrımlarında damarlar ve melanositlerin yanı sıra pekteneal hyalositlere de rastlandı. Yapılan çalışmada elde edilen bulgular ile güvercin pekten okulisinde pekten damarlarının ve melanositlerin koroidden köken aldığı ilk olarak kanıtlanmış bulunmaktadır.
\end{abstract}

Anahtar Kelimeler: Damar, Güvercin, Histomorfoloji, Melanosit, Pekten okuli.

\section{Histomorphological Structure of Pecten Oculi in Pigeons (Columbidae columbiformes)}

\begin{abstract}
It is aimed to research the histomorphological structure of pecten oculi in pigeons and to suggest the differences between other types of avian. Tissue samples from healthy eyes obtained from two pigeons came to the animal hospital were used. Tissue samples were fixed in $10 \%$ neutral-buffered formalin solution for 24 hours. After fixation samples were treated routine procedure and blocked. Serial sections were taken from the blocked. Those sections were examined under the microscope after stained with by Crossman's triple stain. The pecten oculi projects from the optic nerve head into the vitreous chamber. Differently, it was seen that retina in pigeons was not completely separate from pecten base and ganglion cell layer were continued for a bit more. There were vessels with wide diameters on the basal part where pecten was located. This vessel was found to have originated from choroid. It was also seen that vessel diameters got smaller as it went to the apical from the basal. So, the vessels were classified as primer, secondary, and tertiary vessel. Diameters of 20 randomly chosen vessels from each sections were measured and an average diameter value was found. There was also a little amount of melanocyte in the basal part of the pecten. These melanocytes were based on the laminated vasculosa of the choroid. Pecten oculi were covered pecteneal membrane. Besides pecteneal hyalocytes were found in the pecteneal limiting membrane. According to the findings of the study, it was first proven to have originated from choroid that pigeon's veins and melanocytes at the pecten oculi.

Keywords: Vessel, Pigeon, Histomorphology, Melanocyte, Pecten oculi.
\end{abstract}

\section{Giriş}

Kanatlılar kafalarına oranla oldukça büyük gözlere sahiptir (King ve McLelland, 1984). Ayrıca kanatlı gözünde pecten okuli diye adlandırılan eşsiz bir anatomik yapı bulunmaktadır. Pekten okulinin intra oküler basıncı ve $\mathrm{pH}^{\prime} \mathrm{yı}$ dengelediği (Schaepdrijver ve ark., 1989), gözün savunmasında görev aldığı (Uehara ve ark., 1996) ve tamamen damarsız olan kanatlı retinasını beslediği (Kiama ve ark., 2001) düşünülmektedir. Oldukça damarlı ve pigmentli bir organ olan pekten okuli, nervus optikusun retinaya giriş bölgesinden vitreus boşluğuna doğru uzanır (Brach, 1977). Morfolojik olarak, yalnızca Kivi kuşlarında rapor edilen koni tipi pekten okuli, devekuşlarında rapor edilen pervane tipi pekten okuli ve diğer birçok kuş türünde görülen kıvrımlı tip pekten okuli olmak üzere üç grupta sınıflandırılmıştır (Meyer, 1977).

Pekten okuli, nervus optikustan vitreusa doğru uzanırken kıvrımlar yapar. Bu kıvrımların sayısı, şekli ve uzunluğu hayvan türlerine göre farklılık göstermektedir (Braekevelt, 1991; Rahman ve ark., 2010; Smith ve ark., 1996). Yapılan histolojik çalışmalarda pekten okuli kıvrımlarında bol miktarda farklı çaplarda damarlara ve melanositlere 
rastlandığı bildirilmektedir (Braekevelt ve Richardson, 1996; Braekevelt, 1993; Dayan ve Ozaydın, 2013). Elektron mikroskobik çalışmalarda pekten kapillarlarının etrafında perisitlerin varlığından da söz edilmektedir (Braekevelt, 1991a). Pekten okuli vitreo-pekteneal membran adı verilen bir bazal membranla sarılmıştır (Uehara ve ark., 1996). Bazı türlerde bu membran üzerinde hyalosit adı verilen makrofaj benzeri hücrelere rastlanmıştır (Orhan ve ark., 2011; Pourlis, 2013).

Sunulan çalışmada, güvercine ait pekten okulinin histomorfolojik ve histometrik olarak incelenmesi ve diğer kanatlı türleriyle aralarındaki benzerlik ve farklılıkların ortaya konulması amaçlanmıştır.

\section{Materyal ve Metot}

Çalışmada materyal olarak Harran Üniversitesi Veteriner Fakültesi Hayvan Hastanesi'ne getirilen ve kurtarılamayan iki adet yabani güvercinden alınan doku örnekleri kullanıldı. Alınan doku örnekleri \%10 nötral tamponlu formalin solüsyonunda 24 saat tespit edildikten sonra 24 saat yıkamaya alındı. Rutin doku takip prosedürlerine göre dereceli alkollerden ve xylolden geçirilen doku örnekleri parafinde bloklandı. Bloklanan bu doku örneklerinden $5 \mu$ kalınlığında alınan seri kesite Crossman'ın modifiye üçlü boyama yöntemi uygulandı (Crossman, 1937; Denk ve ark., 1989). Boyanan preparatlar araştırma mikroskobunda (Olympus Cover, 018 model) incelendi. Pekten okuli kıvrımlarında gözlenen ve rastgele örnekleme yöntemiyle seçilen primer, sekonder ve tersiyer 20 ayrı damar çapı Bs200Pro görüntü analiz programı (BAB software) ile ölçüldü. Elde edilen verilerin ortalamaları ve standart hataları alınarak her gruba ait damarların ortalama çapları tespit edildi (Tablo 1).

Tablo 1. Primer, sekonder ve tersiyer damarların çaplarına ait veriler $(\mu \mathrm{m})$

\begin{tabular}{|c|c|c|c|c|c|c|c|c|}
\hline $\begin{array}{l}\text { Primer } \\
\text { Damar En }\end{array}$ & $\begin{array}{c}\text { Primer } \\
\text { Damar } \\
\text { Boy }\end{array}$ & $\begin{array}{l}\text { Primer } \\
\text { Çap }\end{array}$ & $\begin{array}{l}\text { Sekunder } \\
\text { Damar En }\end{array}$ & $\begin{array}{l}\text { Sekonder } \\
\text { Damar Boy }\end{array}$ & $\begin{array}{c}\text { Sekonder } \\
\text { Çap }\end{array}$ & $\begin{array}{c}\text { Tersiyer } \\
\text { Damar En }\end{array}$ & $\begin{array}{c}\text { Tersiyer } \\
\text { Damar } \\
\text { Boy }\end{array}$ & $\begin{array}{c}\text { Tersiyer } \\
\text { Çap }\end{array}$ \\
\hline 33.77 & 186.83 & 79.43 & 38.33 & 57.49 & 46.94 & 18.36 & 20.64 & 19.46 \\
\hline 45.53 & 135.43 & 78.52 & 42.3 & 54.05 & 47.81 & 12.35 & 19.02 & 15.32 \\
\hline 64.14 & 331.37 & 145.78 & 46.9 & 68.89 & 56.84 & 16.74 & 16.73 & 16.73 \\
\hline 68.97 & 273.37 & 137.31 & 41.43 & 63.85 & 51.43 & 16.58 & 15.82 & 16.19 \\
\hline 56.25 & 312.98 & 132.68 & 45.58 & 53.4 & 49.33 & 14.65 & 13.9 & 14.27 \\
\hline 58.64 & 300.5 & 132.74 & 42.21 & 87.92 & 60.91 & 12.15 & 19.62 & 15.43 \\
\hline 54.98 & 179.43 & 99.32 & 69.84 & 57.65 & 63.45 & 9.6 & 23.14 & 14.90 \\
\hline 45.58 & 155.06 & 84.06 & 26.21 & 123.01 & 56.78 & 13.72 & 18.29 & 15.84 \\
\hline 79.15 & 148.45 & 108.39 & 17.11 & 83.11 & 37.70 & 14.3 & 46.76 & 25.85 \\
\hline 64.51 & 339.09 & 147.90 & 38.8 & 58.96 & 47.82 & 12.81 & 11.57 & 12.17 \\
\hline 45.86 & 158.04 & 85.13 & 17.76 & 74.61 & 36.40 & 23.62 & 26.52 & 25.02 \\
\hline 52.34 & 209.39 & 104.68 & 34.28 & 64.87 & 47.15 & 12.56 & 15.61 & 14.00 \\
\hline 49.94 & 133.44 & 81.63 & 40.59 & 60.84 & 49.69 & 14.61 & 18.7 & 16.52 \\
\hline 52.24 & 311.43 & 127.55 & 31.08 & 88.19 & 52.35 & 19.1 & 16.09 & 17.53 \\
\hline 53.04 & 127.08 & 82.09 & 50.11 & 111.76 & 74.83 & 12.75 & 24.35 & 17.61 \\
\hline 51.71 & 140.71 & 85.30 & 37.2 & 62.21 & 48.10 & 15.28 & 24.64 & 19.40 \\
\hline 64.4 & 283.37 & 135.08 & 53.38 & 132.84 & 84.20 & 14.65 & 19.13 & 16.74 \\
\hline 49.71 & 351.3 & 132.14 & 33.52 & 189.68 & 79.73 & 16.2 & 24.74 & 20.01 \\
\hline 60.67 & 268.3 & 127.58 & 44.86 & 65.38 & 54.15 & 14.39 & 32.72 & 21.69 \\
\hline Ortalama & & 110.91 & & & 55.03 & & & 17.62 \\
\hline \multicolumn{2}{|c|}{ Standart Sapma } & 24.88 & & & 12.51 & & & 3.48 \\
\hline
\end{tabular}

\section{Bulgular}

Makroskopik incelemeler sonucu, güvercinde pekten okulinin kıvrımlı şekilli olduğu gözlendi. Pekten okuli yaklaşık 14-15 adet fan benzeri kıvrımdan oluşmaktaydı. Pekten geniş bir temel üzerine oturmuştu ve pekten kıvrımları apikalde bir köprüyle birbirine bağlanmaktaydı. Makroskopik olarak bakıldığında, pekten okulinin nervus optikusun göz küresine giriş bölgesinin hemen yanında yer aldığı gözlendi.
Mikroskobik incelemelerde, pekten okuli nervus optikusun retinaya giriş bölgesinde geniş bir temel üzerine (pekten bazali) oturduğu ve buradan da kıvrımlar yaparak apikale doğru uzandığı belirlendi (Şekil 1). Pekten bazalinin sağında ve solunda retina tabakasının olduğu gözlendi. Retinanın pekten bazalinin başladığı kısımda tamamıyla kopuntuya uğramadığı ve retina sinir telleri katının bu temel üzerinde bir süre daha 
devam ettiği belirlendi (Şekil 2). Retina sinir telleri katı pekten kıvrımlarının ortaya çıkmasıyla kaybolduğu, pekten kıvrımlarının ise apikale doğru ilerlerken dirseklenerek geriye doğru döndüğü ve pekten bazaline tekrar bağlandığı gözlendi (Şekil 3).

Pekten bazalinde büyük çaplı damarlara rastlandı. İncelenen kesitlerde koroidin lamina vaskulozasından gelen geniş çaplı bir damarın nervus optikusu delerek pekten bazaline doğru ilerlediği ve pekten kıvrımlarındaki damarlara bağlandığı tespit edildi (Şekil 4, Şekil 5). Pekten bazalinden apikale doğru ilerleyen damarların çaplarının küçüldüğü tespit edildi. Bu nedenle damarlar çaplarına göre primer, sekonder ve tersiyer damarlar olarak sınıflandırıldı. Sınıflandırılan her damar grubundan rastgele 20 tanesinin çapları ölçülerek ortalama damar çapı değerleri elde edildi
(Tablo 1, Şekil 6). Elde edilen verilere bakıldığında pektenin bazalinde ve pekten kıvrımlarının bazal yarıma yakın kısımlarında yoğun olarak gözlenen primer damar çaplarının ortalama $110.91 \pm 24.88 \mu \mathrm{m}$ olduğu belirlendi. Pekten kıvrımlarında apikale doğru gidildikçe primer damarların kaybolduğu gözlendi. Pekten kıvrımların orta kısımların sekonder damarlar bulunmaktaydı. Tersiyer damarlar ise sekonder damarların etrafında pekteneal bazal membrana yakın bölgede yoğunlaşmaktaydı. Tersiyer damarlar tıpkı tespih taneleri gibi art arda iki sıra halinde dizilmekteydi (Şekil 7). Elde edilen veriler değerlendirildiğinde sekonder damarların ortalama çapları $55.03 \pm 12.51 \mu \mathrm{m}$ olarak tespit edilirken tersiyer damarların ortalama çapları 17.62 \pm 3.48 olarak belirlendi (Tablo 1, Şekil 6).

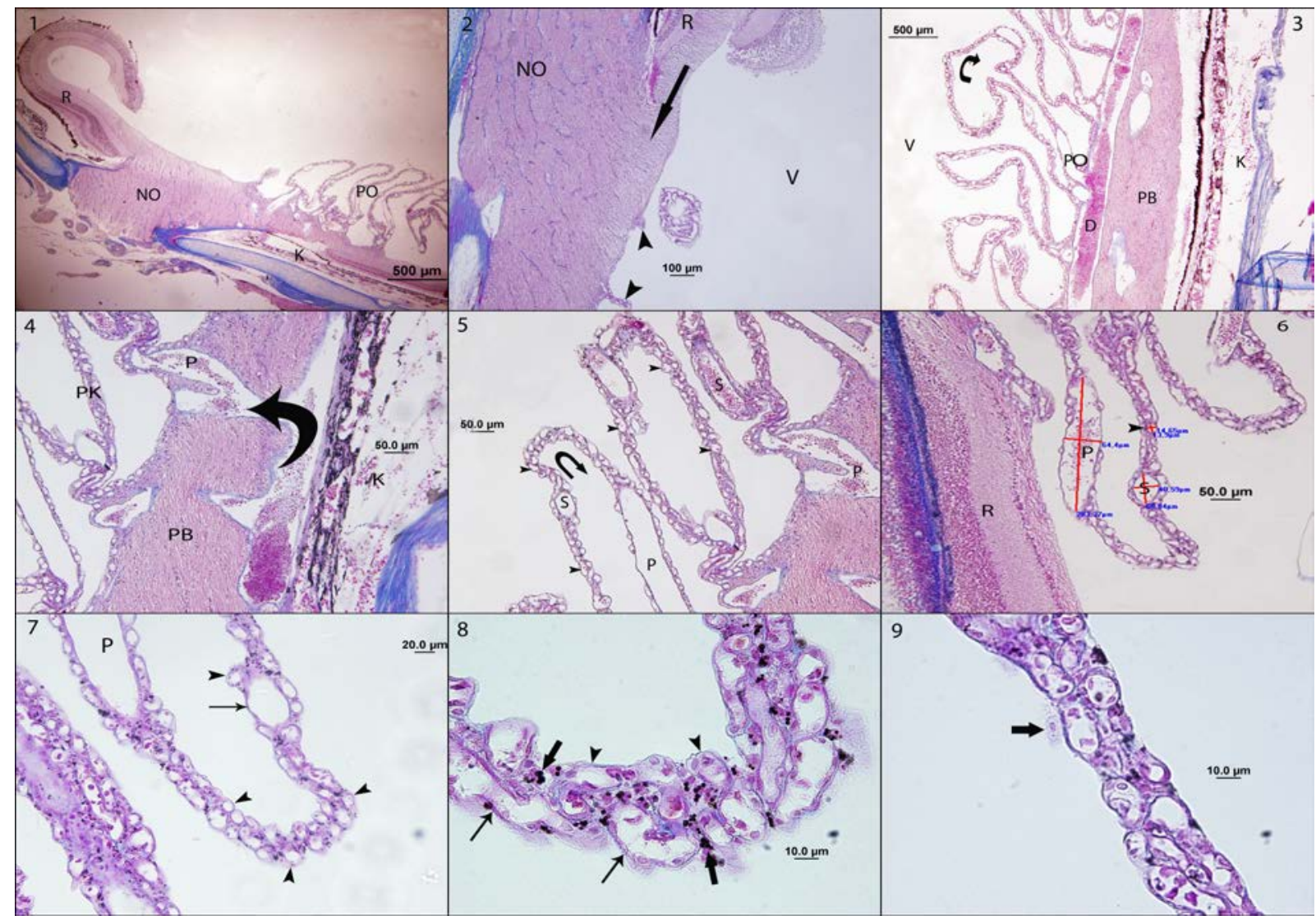

Şekil 1-3. Güvercinde pekten okulinin genel histolojik görünümü. D: Damar, K: Koroid, PB: Pekten Bazali, PO: Pekten Okuli, R: Retina, V: Vitreus, ok: Retina sinir telleri katı, ok başları: Pekten kıvrımlarının başlangıcı, kıvrılmış ok: Pekten kıvrımının dirseklenmesi. Şekil 4-5. Güvercinde pekten okulinin ve damarlarının histolojik görünümü. K; Koroid, PB; Pekten bazali, PK; Pekten kıvrımı, P; Primer damar, S; Sekonder damar, kalın eğik ok; Koroidden gelen damar, ince kıvrılmış ok; Pekten dirseklenmesi, ok başları; Tersiyer damarlar. Şekil 6. Güvercinde pekten okuli damar çaplarının ölçümü. R: Retina, P: Primer damar, S: Sekonder damar, ok başları: Tersiyer damar. Şekil 7. Güvercinde pekten okuli damarlarının histolojik görünümü. P: Primer damar, ok: Sekonder damar, ok başı: Tersiyer damar. Şekil 8. Güvercinde pekten kıvrımlarının histolojik görünümü. Kalın ok: Melanosit, ince oklar: Sekonder damar, ok başları: Tersiyer damar. Şekil 9. Güvercinde pekten kıvrımının histolojik görünümü. Ok: Hyalosit.

Pektenin bazal kısmında primer damarlar dışında az miktarda melanositlere de rastlandı. Bu melanositlerin çoğunlukla koroidden gelen damarların etrafında bulunduğu ve yoğunluklarının apikale doğru gidildikçe arttığı gözlendi. Her ne kadar bu hücrelerin sekonder ve tersiyer damarların aralarını doldurmuş oldukları gözlense de başlıca pekteneal membranın altında yoğunlaştığı tespit 
edildi. Önceden çalışılan diğer kanatlı türleriyle karşılaştırıldığında ise güvercin pekten okulisinde bulunan melanositlerin yoğunluğunun daha az olduğu belirlendi (Şekil 8).

Pekteneal membranla çevrili olan pekten okulide membranın hemen üstünde pekten kıvrımlarına yapışık halde pekteneal hyalositlerin de bulunduğu tespit edildi (Şekil 9). Melanositlere benzer şekilde bu hücrelerin de diğer kanatlı türlerine göre güvercinlerde daha seyrek olarak görüldüğü tespit edildi.

\section{Tartışma ve Sonuç}

Yapılan çalışmalarda, yalnızca kanatlı gözünde bulunan ve birçok farklı fonksiyona sahip olduğu düşünülen pekten okuli yapısının hayvan türlerine göre değiştiği belirlenmiştir (Braekevelt, 1991; Orhan ve ark., 2011; Rahman ve ark., 2010). Pekten okulinin şekli, uzunluğu ve pekten kıvrımlarının sayısı türlere göre farklılık göstermektedir. Avustralya Galah'ında (Braekevelt ve Richardson, 1996) ve Japon orman kargalarında (Rahman ve ark., 2010) yaklaşık 20-25 adet fan şeklinde pekten kıvrımı tespit edildiği bildirilirken baykuşta akordion benzeri 8-10 kıvrım (Smith ve ark., 1996) ve büyük mavi balıkçılda (Braekevelt, 1991a) fan benzeri yaklaşık 10-14 kıvrım bulunduğu bildirilmiştir. Sunulan çalışmada, güvercinlerde yaklaşık 15 adet fan benzeri pekten kıvrımı olduğu tespit edildi. Güvercinlerin kıvrım sayısının balıkçıllar gibi küçük kafalı kuşlara benzer olduğu belirlendi. Bununla birlikte güvercinde pekten kıvrımlarının apikale doğru ilerlerken kıvrım yaparak geri döndüğü ve tekrar bazale bağlandığı gözlemlendi. Bu oluşum, güvercinde pekten okulinin şeklinin neden kemer biçimde (Tucker, 1975) göründüğünü ortaya koymaktadır. Şekilleri farklı olsa da tüm kanatlı pekten okulilerinde, bol miktarda kapillar damarlar ve melanositlere rastlandığı belirtilmektedir (Dayan ve Ozaydın, 2013). Elektron mikroskobik incelemelerde ise kapillar damarların etrafında perisitlerin de bulunduğu bildirilmektedir (Braekevelt, 1991a). Sunulan çalışmada, diğer kanatlı türlerine benzer şekilde güvercinlerde de bol miktarda kapillar damar bulunduğu ancak melanositlerin ve hyalositlerin yoğunluğunun az olduğu belirlendi.

Yapılan araştırmalarda, pekten kıvrımlarında bulunan kapillar damarların hayvan türüne bağlı olarak farklı çapta ve yoğunlukta olabileceği belirlenmiştir. Bazı çalışmalarda pekten kıvrımlarında büyük çaplı damarlar ve kapillarların varlığından söz edilmektedir (Rahman ve ark., 2010). Diğer bazı çalışmalarda ise afferent ve efferent damarlar olarak adlandırılan büyük ve küçük çaplı damarlardan bahsedilmektedir (Onuk ve ark., 2013).
Yapılan komparatif bir çalışmada (Dayan ve Ozaydın, 2013) ise farklı hayvan türleri arasında pekten damarlarının çapı karşılaştırılmış ve devekuşu, ördek, güvercin, hindi ve sığırcıkta ortalama damar çapları sırasıyla 20.23, 14.34, 11.78, 12.58 ve 12.78 $\mu \mathrm{m}$ olduğu bildirilmiştir. Güvercinlerde yapılan bu çalışmada ise üç farklı çapta damar olduğu dikkati çekti. Bu nedenle damarlar primer, sekonder ve tersiyer damarlar olarak sınıflandırıldı. Primer damarların pekten bazalinden başladığı ve pekten kıvrımlarının bazale yakın kısmında yoğunlaştığı belirlendi. Sekonder ve tersiyer damarların ise pekten kıvrımlarının apikale doğru uzanan kısımlarında olduğu gözlendi. Sekonder damarlar kıvrımların ortasında yer alırken tersiyer damarların bunları sardığı ve pekteneal membran altında yerleştiği dikkati çekti. Pekten kıvrımının en apikaline doğru ise tersiyer damarların iki sıra halinde boncuk gibi dizildiği ve sayılarının yoğunlaştığı gözlemlendi. Sunulan çalışmada, pekten kıvrımlarında damar çapları ölçüldüğünde primer damar çaplarının ortalama 110.91 $\$ 24.88 \mu \mathrm{m}$, sekonder damar çaplarının ortalama $55.03 \pm 12.51$ $\mu \mathrm{m}$ mikrometre ve tersiyer damar çaplarının ortalama $17.62 \pm 3.48 \mu \mathrm{m}$ olduğu belirlendi.

Pekten okulinin tüm kanatlılarda pekteneal sınırlayıcı membran adı verilen ince bir bağ dokuyla çevrelendiği bildirilmektedir (Brach, 1977; Smith ve ark., 1996). Bazı kanatlı türlerinde bu bağ doku etrafında hyalosit adı verilen ve makrofaj benzeri hücre olarak adlandırılan hücrelere de rastlanılmaktadır (Korkmaz ve Kum, 2016). Tavuk (Uehara ve ark., 1996) ve ördekte (Braekevelt, 1998) pekteneal hyalosit varlığından söz edilmekteyken kırmızı kuyruklu atmaca (Braekevelt, 1991) ve kargada (Braekevelt, 1994) hyalositlere rastlanmadığı bildirilmiştir. Sunulan çalışmada tıpkı tavuk ve ördekte olduğu gibi güvercinlerde de pekteneal hyalositler tespit edildi.

Sonuç olarak, güvercinlerde pekten okulinin yapısı histomorfolojik olarak ortaya konuldu. Daha önce çeşitli kanatlı türlerinde pekten okuli üzerine yapılmış sayısız araştırma bulunmaktadır (Braekevelt, 1994; Smith ve ark., 1996). Sunulan çalışmada yaban güvercininde pekten okulinin yapısı histomorfolojik olarak incelendi ve pekten kıvrım sayısı yönünden balıkçıllarla, damar yoğunluğu ile diğer birçok kanatlı türüyle benzerlik gösterdiği ortaya konuldu. Pekten okulinin embriyolojik dönemde koroid yarığının kapanması sırasında ortaya çıktığı ve koroidden köken aldığı bildirilmektedir (Romanoff, 1960). Ancak erişkin kanatlı türleriyle ilgili şimdiye kadar yapılan çalışmalarda kroid-pekten ilişkisine dair herhangi bir verinin ortaya konmadığı görülmektedir. Sunulan çalışmada yaban güvercininin pekten okuli bölgesinde yer alan kapillarının koroidin lamina 
vaskulosa'sından çıkan büyük çaplı damarlarla olan bağlantısı ortaya kondu. Pekten okulide bulunan damarların çapları göz önünde bulundurulduğunda primer, sekonder ve tersiyer damarlar olarak 3 grupta incelenebileceği belirlendi. Yapılan çalışmanın bu yönüyle birçok çalışmaya kaynak oluşturacağı ve daha detaylı çalışmalarla pekten okuli için türlerde form-fonksiyon ilişkisinin irdelenebileceği düşünülmektedir.

\section{Kaynaklar}

Brach V, 1977: The functional significance of the avian pecten: a review. Condor, 79, 321-327.

Braekevelt CR, 1991: Electron microscopic observation on the pecten oculi of the Gread Blue Heron. Histol Histopathol, 6, 345-351.

Braekevelt, CR, 1991a: Fine structure of the pecten oculi in the Red-Tailed Hawk. Anat Histol Embryol, 8, 9-15.

Braekevelt CR, 1993: Fine structure of the pecten oculi in the Great Horned Owl. Histol Histopathol, 8, 9-15.

Braekevelt CR, 1994: Fine structure of the pecten oculi in the American crow. Anat Histol Embryol 23, 357366.

Braekevelt CR, 1998: Fine structure of the pecten oculi of the emu. Tissue Cell 30, 157-165.

Breakevelt CR, Richardson KC, 1996: Fine structure of the pecten oculi in the Australian Galah (Eolophus roseicapillus) (Aves). Histol Histopathol, 11, 565-571.

Crossman G, 1937: A modification of Mallory's connective tissue stain with a discussion of the principles involved. Anat Rec, 69, 33-38.

Dayan MO, Ozaydin TA, 2013: Comparative morphomertical study of the pecten oculi in different avian species. Sci World J, http://dx.doi.org/10.1155/2013/968652

Denk H, Kunzele H, Plenk H, Ruschoff J, Sellner W, 1989: Romeis microscopische tecnic, 17, Neubearbeitete Auflage. Urban und Schwarzenberg, München, Wien, Baltimore, 439-450.

Kiama SG, Maina JN, Bhattacharjee J, Weyrauch KD, 2001: Functional morphology of the pecten oculi in the nocturnal spotted eagle owl (Bubo bubo africanus), and the diurnal black kite (Milvus migrans) and domestic fowl (Gallus gallusvar. domesticus): a comparative study. J Zool 254, 521-528.
King AS, McLelland J, 1984: Special sense organs. In: King AS, McLelland J, editors. Birds: Their structure and function, 2nd ed. London: Baillie _ee Tindall. pp. 284-314.

Korkmaz D, Kum S, 2016: Investigation of the antigen recognition and presentation capacity of pecteneal hyalocytes in the chicken (Gallus gallus domesticus). Biotech \& Histochem, 91, 3, 212-219.

Meyer DB, 1977: The avian eye and its adaptations. In: Handbook of sensory physiology. Vol V1115. The visual system in vertebrates. Crescitelli F. (ed). Springer-Verlag. Berlin. 549-612.

Onuk B, Tutuncu S, Alan A, Kabak M, 2013: Macroanatomic, light and scanning electron microscopic studies of the pecten oculi in the stork (Ciconia ciconia) Microsc Res and Tech, 76, 963-967.

Orhan, OI, Ekim O, Bayraktaroğlu AG, 2011: Morphological investigation of the pecten oculi in quail (Coturnix coturnix Japonica). J Fac Vet Med Univ Ankara, 58, 510.

Pourlis AF, 2013: Scanning electron microscopic studies of the pecten oculi in the quail (Coturnix coturnix Japonica). Anat Res Int, http://dx.doi.org/10.1155/013/650601.

Rahman ML, Lee E, Aoyama M, Suqita S, 2010: Light and electron microscopy study of the pecten oculi of the jungle crow (Corvus macrorhynchos). Okajimas Folia Anat Jpn, 87, 75-83

Romanoff AL, 1960: The avian embryo: structural and functional development. 1st ed . Brett-Macmillan Ltd., Gald-Ontorio. pp. 397-404.

Schaepdrijver L de, Simoens P, Lauwers $H$, Geest JP de, 1989: Retinal vascular patterns in domestic animals. Res Vet Sci, vol. 47, 1, 34-42.

Smith BJ, Smith SA, Braekevelt CR, 1996: Fine structure of the pecten oculi of the barred owl (Strix varia). Histol Histopathol, 11, 1, 89-96.

Tucker R, 1975: The surface of the pecten oculi in the pigeon. Cell Tiss Res, 157, 457-465.

Uehara M, Imagawa T, Kitagawa H, 1996: Morphological studies of the hyalocytes in the chicken eye: scanning electron microscopy and inflammatory response after the intravitreous injection of carbon particles. J Anat, 188, 3, 661-669.

Yazışma Adresi: Deniz KORKMAZ

Harran Üniversitesi, Veteriner Fakültesi, Histoloji Embriyoloji Anabilim Dalı, Şanlıurfa, Türkiye. e-mail: dekork@gmail.com 